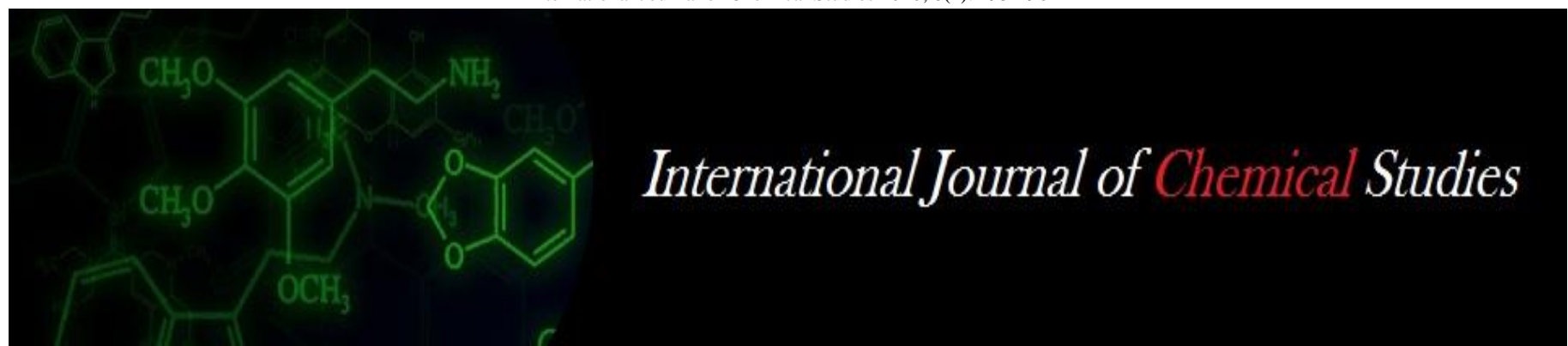

P-ISSN: 2349-8528

E-ISSN: 2321-4902

www.chemijournal.com

IJCS 2020; 8(2): 293-296

(C) 2020 IJCS

Received: 01-01-2019

Accepted: 05-02-2019

Soma Devi

College of Agriculture, Swami

Keshwanand Rajasthan

Agricultural University, Bikaner,

Rajasthan, India

\section{SP Singh}

College of Agriculture, Swami

Keshwanand Rajasthan

Agricultural University, Bikaner,

Rajasthan, India

\section{Amit Kumawat}

College of Agriculture, Swami

Keshwanand Rajasthan

Agricultural University, Bikaner,

Rajasthan, India
Corresponding Author: Soma Devi

College of Agriculture, Swami

Keshwanand Rajasthan

Agricultural University, Bikaner,

Rajasthan, India

\title{
Response of wheat (Triticum aestivum L.) to nitrogen levels and seed rate under different tillage conditions
}

\section{Soma Devi, SP Singh and Amit Kumawat}

DOI: https://doi.org/10.22271/chemi.2020.v8.i2e.8782

\section{Abstract}

A field experiment entitled "Response of wheat (Triticum aestivum L.) to nitrogen levels and seed rate under different tillage conditions" was conducted on loamy sand soil at Agronomy Farm, College of Agriculture, Swami Keshwanand Rajasthan Agricultural University, Bikaner during rabi seasons of 2015-16 and 2016-17. The results of experiment showed that conventional tillage significantly increased the growth attributes viz., yield attributes (effective tillers per meter row length, spike length and grains per spike), grain, straw and biological yields, over zero and minimum tillage. The highest net returns (₹40118 ha $^{-1}$ ) with B:C ratio of 2.51 were also obtained in conventional tillage over zero and minimum tillage. Seed rate of $125 \mathrm{~kg} \mathrm{ha}^{-1}$ significantly increased the grain, straw and biological yields of wheat, as compared to seed rate of $100 \mathrm{~kg} \mathrm{ha}^{-1}$. The highest net returns (₹39902 ha-1) with B:C ratio of 1.60 were also obtained in seed rate of $125 \mathrm{~kg} \mathrm{ha}^{-1}$ over seed rate of $100 \mathrm{~kg} \mathrm{ha}^{-1}$. Application of $120 \mathrm{~kg} \mathrm{~N} \mathrm{ha}{ }^{-1}$ significantly increased the growth attributes viz., yield attributes (effective tillers per meter row length, spike length and grains per spike), grain, straw and biological yields over 80 and $100 \mathrm{~kg} \mathrm{~N} \mathrm{ha}{ }^{-1}$. The highest net returns (₹41835 ha-1) with B:C ratio of 1.70 were also obtained in $120 \mathrm{~kg} \mathrm{~N} \mathrm{ha}^{-1}$. The combined application of $120 \mathrm{~kg} \mathrm{~N} \mathrm{ha}^{-1}$ in combination with conventional tillage proved as good as 140 $\mathrm{kg} \mathrm{N} \mathrm{ha}^{-1}$ with conventional tillage in respect of effective tillers per metre row length, number of grains per spike, grain, straw and biological yield.

Keywords: Conventional tillage, minimum tillage, zero tillage grain yield

\section{Introduction}

India stands in second position next to China in the world with regard to area and production of wheat. In India wheat is grown on $31.5 \mathrm{~m}$ ha with total production of $86.5 \mathrm{MT}$ with average productivity of $2750 \mathrm{~kg} \mathrm{ha}^{-1}$ (Anonymous, 2015a). In Rajasthan, it is cultivated on $3.3 \mathrm{~m}$ ha with total production of 9.8 MT and average productivity of $2961 \mathrm{~kg} \mathrm{ha}^{-1}$. The productivity of wheat in the Western Rajasthan is lower $\left(858 \mathrm{~kg} \mathrm{ha}^{-1}\right)$ than the potential yield (Anonymous, $2015 b)^{[1]}$. Large numbers of factors are responsible for stagnation in wheat yields in North Western India such as late planting, inappropriate crop establishment, inadequate and imbalanced nutrient management and degrading soil health. Growing labour and water shortages, increasing cost of fuel, changing climatic conditions are likely to further affect the productivity of wheat adversely (Saharawat et al., 2010) ${ }^{[11]}$. Traditionally, farmers typically perform multiple tillage operations after Kharif crop harvest to prepare field for wheat planting. The intensive tillage contributes to increased cost of cultivation leading to decreased profitability (Chhokar et al., 2007; Ladha et al., 2009) ${ }^{[2,6]}$. Increased use of machinery and repeated tillage operations also emit large amount of greenhouse gases (GHGs) into the atmosphere. Recently, alternative tillage options such as minimum and zero tillage has emerged as an important management strategy to address many of the pressing challenges confronting intensified wheat systems in NW India. No-tillage has been widely adopted by farmers in wheat production, particularly in North Western India, primarily to facilitate early planting of wheat, to lower production cost and increase yield so as to increase profitability (Chhokar et al., 2007) ${ }^{[2]}$. 


\section{Material and Methods}

The experiment was conducted at the Instructional farm, College of Agriculture, Swami Keshwanand Rajasthan Agricultural University, Bikaner during rabi seasons of 201516 and 2016-17. College of Agriculture is situated on Sriganganagar road at $28.01^{\circ} \mathrm{N}$ latitude and $73.22^{\circ} \mathrm{E}$ longitude at an altitude of $234.7 \mathrm{~m}$ above mean sea level. According to "Agro-ecological region map" brought out by National Bureau of Soil Survey and Land Use Planning (NBSS\&LUP), Bikaner falls under Agro-ecological region No. 2 (M9E1) under Arid ecosystem (Hot Arid Eco-region), which is characterized by deep, sandy and coarse loamy, desert soils with low water holding capacity and hot and arid climate. Annual PET in this region ranges between 1500-2000 mm. As per NARP classification of agro-climatic zones, Bikaner falls in Agro-climatic zone Ic (Hyper Arid Partially Irrigated Western Plain Zone). According to National Planning Commission, Bikaner falls under Agro-climatic zone XIV (Western Dry Region) of India and The field experiment was laid out in a split plot design with three replications comprising 3 levels of tillage (conventional, minimum and zero tillage) and 2 levels of seed rate (100 and $\left.125 \mathrm{~kg} \mathrm{ha}^{-1}\right)$ thus 6 treatment combinations of tillage and seed rate in main plots and 4 levels of nitrogen $\left(80,100,120\right.$ and $\left.140 \mathrm{~kg} \mathrm{~N} \mathrm{ha}^{-1}\right)$ in sub-plots and comprising a total of 24 treatment combinations.

\subsection{Varietal characters}

Raj-4120: It is a dwarf variety of wheat suitable for western plains zone under irrigated conditions. The grains are amber medium bold semi-hard having around $38 \mathrm{~g}$ average 1000 grain weight with good chapatti making quality. It is about $80-90 \mathrm{~cm}$ in height and takes $115-118$ days in maturity. Its yield potential is about $40-45 \mathrm{q} \mathrm{ha}^{-1}$.

Grain yield: The grain yield of each net plot (inclusive of tagged plants) was recorded in $\mathrm{kg}$ per plot after cleaning the threshed produce was converted as $\mathrm{kg} \mathrm{ha}^{-1}$.

Harvest index (\%): The harvest index was calculated by using following formula and expressed as percentage (Singh and Stoskopf, 1971).

$$
\text { Harvest index }(\%)=\frac{\text { Economic yield }(\mathrm{kg} / \mathrm{ha})}{\text { Biological yield }(\mathrm{kg} / \mathrm{ha})} \times 100
$$

\subsection{Benefit: cost ratio}

Treatment wise benefit: cost ratio was calculated to ascertain economic viability of the treatment using following formula:$$
\text { B: } \mathrm{C} \text { ratio }=\frac{\text { Gross returns }\left(₹ \mathrm{ha}^{-1}\right)}{\text { Cost of cultivation }\left(\mathrm{F}_{\mathrm{ha}}^{-1}\right)}
$$

\subsection{Statistical analysis}

In order to test the significance of variance in experiments, the data obtained for various treatment effects were statistically analysed as per procedure described by Panse and Sukhatme (1985) ${ }^{[10]}$. The critical differences were calculated to assess the significance of treatment means wherever, the "F" test was found significant at 5 per cent and 1 per cent level of significance. The analysis of variance for all the data presented and discussed has been given in appendices at the end.

\section{Results and Discussion}

The ultimate effect of experimental variables is reflected in the final yield of crop and thus, it is a major criterion to identify the efficiency of various treatments in a given situation. The per cent increase in grain yield with the conventional tillage was 9.01 and 4.19 per cent in pooled mean over zero and minimum tillage, respectively. Seed rate of $125 \mathrm{~kg} \mathrm{ha}^{-1}$ increased the stover yield by 4.69 per cent in pooled mean over $100 \mathrm{~kg} \mathrm{ha}^{-1}$ seed rate. Straw yield is also an important parameter of the biological yield to evaluate the harvest index and makes some contribution to the crop value. $\mathrm{CT}$ was able to produce significantly higher grain and straw yields compared ZT and MT but the difference between ZT and MT were only marginal (Table 1). The increase in grain yield of wheat under CT could be attributed to higher yield attributes whereas the increase in biological yield was due to higher dry matter production. To some extent it could also attributed to better soil environment (Idnani \& Kumar 2012) [3]. This was probably due to better rooting induced by reduced soil strength in the upper $10-15 \mathrm{~cm}$ layer. The per cent improvement in mean number of grains per spike with conventional tillage was 10.48 and 4.50 per cent in pooled mean over zero and minimum tillage, respectively. The increase in spike length under pooled mean due to application of $120 \mathrm{~kg} \mathrm{~N} \mathrm{ha}^{-1}$ was to the extent of 29.27 and 8.58 per cent over 80 and $100 \mathrm{~kg} \mathrm{~N} \mathrm{ha}{ }^{-1}$, respectively. revealed that different tillage practices, seed rate and increasing levels of nitrogen did not show any significant effect on test weight of wheat during both the years of experimentation as well as in pooled analysis. Yield of any crop depends on the source-sink relationship and is the cumulative function of various growth parameters and yield attributing components viz., number of effective tillers, number of grains per spike, spike length and 1000-grain weight. Yield of wheat often had a positive correlation with LAI and RGR (Watson et al., 1963) ${ }^{[15]}$ and any effect on these parameters by any treatment ultimately affects the biological and economic yields of crop.

Different seed rates affect the yield attributes and yield of wheat crop at harvest stage in terms of number of effective tillers, number of grains per spike, spike length, grain yield, straw yield, biological yield. Seed rate of $125 \mathrm{~kg} \mathrm{ha}^{-1}$ caused significant difference in number of effective tillers than at 100 $\mathrm{kg} \mathrm{ha}^{-1}$ seed rate. While number of grains per spike and spike length increased significantly with decrease in seed rate. With the decrease in seed rate from 125 to $100 \mathrm{~kg} \mathrm{ha}^{-1}$, all yield attributes except effective tillers and yields significantly decreased due to lower number of plants and less number of tillers per meter row length which in turn decreased the LAI. Decreased LAI led to lower photosynthetic efficiency which unfavourably affects the yield contributing parameters. The similar response of decrease in yield and yield attributes with decreasing seed rates have been reported by Iqbal et al. (2010) ${ }^{[4]}$ and Laghari et al. (2011) ${ }^{[7]}$.

Maximum grain yield was produced from $125 \mathrm{~kg} \mathrm{ha}^{-1}$ seeding rates as compared to $100 \mathrm{~kg} \mathrm{ha}^{-1}$ seeding rates which produced minimum grain yield. This might be due to the fact that more number of plants emerged $\mathrm{m}^{-2}$ with more branches, more well filled spikes and plump seed, which in return yielded more grain yield. Our results supported by Mahboob et al. (2005) ${ }^{[8]}$ who reported that planting dates and seeding rates had significant effect on the grain yield. Sharma and Singh, $2011^{[13]}$ also reported that seed rate of $125 \mathrm{~kg} \mathrm{ha}^{-1}$ gave $4.0 \%$ more wheat grain yield than $100 \mathrm{~kg}$ seed/ha which 
in turn recorded $20.0 \%$ and $26.0 \%$ more grain yield than 75 and $150 \mathrm{~kg}$ seeds $\mathrm{ha}^{-1}$, respectively. However, Sandhu et al. (2010) ${ }^{[12]}$ observed that increasing trend in grain yield of wheat with increasing in seed rates. Selection of appropriate plant density for higher productivity depends mainly on tillering and lodging. High plant density beyond optimum leads to mutual competition among plants due to which it fails to exploit the inputs fully. Economic yield is the ultimate goal of all crop production pursuits. The data showed that minimum straw yield was found in the plots where seed rate of $100 \mathrm{~kg} \mathrm{ha}^{-1}$ was used and there was increased as the seed rate increased and highest straw yield was recorded from the plots where seed rate of $125 \mathrm{~kg} \mathrm{ha}^{-1}$ was applied. This might be due to the fact that higher seed rates might result in more plant population which resulted in higher straw yield. The trend of result was almost the same during both the experimental years and pooled data also reflected the same results. Since, biological yield is a function of seed and straw yield representing vegetative and reproduction growth of crop (Table 2). The increase in straw and biological yield with increase in seed rate was also reported by earlier researchers (Sharma and Singh, 2011 ${ }^{[13]}$ and Tigabu and Asfaw (2016) [14].

The highest pooled mean net returns (₹40118/ha) with B:C ratio of 1.51 were obtained in conventional tillage over zero and minimum tillage. The pooled mean net return was higher by ₹ 2274 and 859 under conventional tillage as compared to zero and minimum tillage, respectively. The highest significant pooled mean net returns (₹41835 ha-1) and B:C ratio (1.70) were obtained in $120 \mathrm{~kg} \mathrm{~N} \mathrm{ha}^{-1}$ over 80 and 100 $\mathrm{kg} \mathrm{N} \mathrm{ha}^{-1}$. The pooled mean net return was higher by ₹ 8950 and 3504 under $120 \mathrm{~kg} \mathrm{~N} \mathrm{ha}^{-1}$ as compared to 80 and $100 \mathrm{~kg}$ $\mathrm{N} \mathrm{ha}{ }^{-1}$, respectively. Each successive increment in nitrogen levels exhibited higher net return as well as B:C ratio. Each incremental dose of nitrogen resulted in proportionate increase in grain yield surplusing the extra cost incurred towards nitrogen fertilizers. These results are also in the line with the findings of Kumar and Yadav (2005) ${ }^{[5]}$, Mitra et al., (2014) ${ }^{[9]}$.

Table 1: Effect of tillage, seed rate and nitrogen levels on yields of wheat

\begin{tabular}{|c|c|c|c|c|c|c|c|c|c|c|c|c|}
\hline \multirow{3}{*}{ Treatments } & \multicolumn{9}{|c|}{ Yield $\left(\mathrm{kg} \mathrm{ha}^{-1}\right)$} & \multirow{2}{*}{\multicolumn{3}{|c|}{ Harvest index (\%) }} \\
\hline & \multicolumn{3}{|c|}{ Grain } & \multicolumn{3}{|c|}{ Stover } & \multicolumn{3}{|c|}{ Biological } & & & \\
\hline & 2015-16 & 2016-17 & Pooled & $2015-16$ & 2016-17 & Pooled & $2015-16$ & 2016-17 & Pooled & 2015-16 & 2016-17 & Pooled \\
\hline \multicolumn{13}{|c|}{ Tillage } \\
\hline ZT & 2953 & 2843 & 2898 & 4091 & 4038 & 4064 & 7044 & 6881 & 6962 & 41.9 & 41.3 & 41.6 \\
\hline MT & 3075 & 2990 & 3032 & 4458 & 4278 & 4368 & 7533 & 7268 & 7401 & 40.8 & 41.2 & 41.0 \\
\hline $\mathrm{CT}$ & 3212 & 3106 & 3159 & 4767 & 4447 & 4607 & 7979 & 7552 & 7766 & 40.2 & 41.2 & 40.7 \\
\hline S.Em \pm & 37 & 35 & 25 & 50 & 49 & 35 & 85 & 84 & 60 & 0.12 & 0.03 & 0.06 \\
\hline $\mathrm{CD}(\mathrm{P}=0.05)$ & 111 & 106 & 73 & 153 & 149 & 102 & 257 & 254 & 173 & NS & NS & NS \\
\hline \multicolumn{13}{|c|}{ Seed rate $\left(\mathrm{kg} \mathrm{ha}^{-1}\right)$} \\
\hline 100 & 3033 & 2927 & 2980 & 4352 & 4142 & 4247 & 7385 & 7069 & 7227 & 41.1 & 41.5 & 41.3 \\
\hline 125 & 3127 & 3032 & 3079 & 4526 & 4366 & 4446 & 7652 & 7398 & 7525 & 40.9 & 41.0 & 40.9 \\
\hline S.Em \pm & 30 & 29 & 21 & 41 & 40 & 29 & 69 & 68 & 49 & 0.09 & 0.03 & 0.05 \\
\hline $\mathrm{CD}(\mathrm{P}=0.05)$ & 91 & 87 & 60 & 125 & 121 & 83 & 210 & 208 & 141 & NS & NS & NS \\
\hline \multicolumn{13}{|c|}{ Nitrogen levels $\left(\mathrm{kg} \mathrm{ha}^{-1}\right)$} \\
\hline 80 & 2707 & 2713 & 2710 & 3948 & 3908 & 3928 & 6656 & 6620 & 6638 & 40.8 & 40.9 & 40.9 \\
\hline 100 & 3048 & 2925 & 2987 & 4401 & 4186 & 4294 & 7449 & 7112 & 7280 & 41.0 & 41.2 & 41.1 \\
\hline 120 & 3238 & 3104 & 3171 & 4636 & 4417 & 4527 & 7874 & 7521 & 7698 & 41.1 & 41.3 & 41.2 \\
\hline 140 & 3326 & 3176 & 3251 & 4770 & 4505 & 4638 & 8096 & 7681 & 7889 & 41.1 & 41.4 & 41.2 \\
\hline S.Em \pm & 48 & 37 & 30 & 65 & 47 & 40 & 111 & 82 & 69 & 0.14 & 0.13 & 0.10 \\
\hline $\mathrm{CD}(\mathrm{P}=0.05)$ & 138 & 105 & 86 & 186 & 135 & 113 & 317 & 233 & 194 & NS & NS & NS \\
\hline
\end{tabular}

Table 2: Effect of tillage, seed rate and nitrogen levels on yield attributes of wheat

\begin{tabular}{|c|c|c|c|c|c|c|c|c|c|c|c|c|}
\hline \multirow{2}{*}{ Treatments } & \multicolumn{3}{|c|}{ Effective tillers (No. $\mathrm{m}^{-2}$ ) } & \multicolumn{3}{|c|}{ Spike length $(\mathrm{cm})$} & \multicolumn{3}{|c|}{ Grains per spike } & \multicolumn{3}{|c|}{ Test weight $(\mathrm{g})$} \\
\hline & 2015-16 & 2016-17 & Pooled & 2015-16 & 2016-17 & Pooled & 2015-16 & 2016-17 & Pooled & 2015-16 & 2016-17 & Pooled \\
\hline \multicolumn{13}{|c|}{ Tillage } \\
\hline ZT & 76.3 & 74.6 & 75.5 & 7.25 & 6.96 & 7.10 & 32.1 & 31.0 & 31.5 & 38.9 & 38.3 & 38.6 \\
\hline MT & 79.1 & 77.3 & 78.2 & 8.07 & 7.80 & 7.94 & 33.7 & 32.8 & 33.3 & 39.3 & 38.7 & 39.0 \\
\hline CT & 80.3 & 78.9 & 79.6 & 8.72 & 8.50 & 8.61 & 35.4 & 34.2 & 34.8 & 40.1 & 39.2 & 39.7 \\
\hline S.Em \pm & 0.7 & 0.7 & 0.5 & 0.11 & 0.08 & 0.07 & 0.4 & 0.4 & 0.3 & 0.5 & 0.6 & 0.4 \\
\hline $\mathrm{CD}(\mathrm{P}=0.05)$ & 2.0 & 2.2 & 1.4 & 0.32 & 0.23 & 0.19 & 1.2 & 1.1 & 0.8 & NS & NS & NS \\
\hline \multicolumn{13}{|c|}{ Seed rate $\left(\mathrm{kg} \mathrm{ha}^{-1}\right)$} \\
\hline 100 & 76.9 & 75.8 & 76.4 & 8.52 & 8.24 & 8.38 & 34.5 & 33.7 & 34.1 & 39.2 & 38.5 & 38.8 \\
\hline 125 & 80.2 & 78.1 & 79.1 & 7.51 & 7.27 & 7.39 & 33.0 & 31.7 & 32.3 & 39.8 & 38.9 & 39.4 \\
\hline S.Em \pm & 0.5 & 0.6 & 0.4 & 0.09 & 0.06 & 0.05 & 0.3 & 0.3 & 0.2 & 0.4 & 0.5 & 0.3 \\
\hline $\mathrm{CD}(\mathrm{P}=0.05)$ & 1.6 & 1.8 & 1.2 & 0.27 & 0.19 & 0.16 & 1.0 & 0.9 & 0.6 & NS & NS & NS \\
\hline \multicolumn{13}{|c|}{ Nitrogen levels $\left(\mathrm{kg} \mathrm{ha}^{-1}\right)$} \\
\hline 80 & 74.5 & 73.3 & 73.9 & 6.63 & 6.48 & 6.56 & 30.8 & 30.0 & 30.4 & 38.5 & 37.8 & 38.2 \\
\hline 100 & 77.7 & 76.1 & 76.9 & 7.95 & 7.67 & 7.81 & 33.0 & 32.1 & 32.6 & 39.7 & 38.7 & 39.2 \\
\hline 120 & 80.5 & 78.4 & 79.5 & 8.61 & 8.35 & 8.48 & 35.1 & 33.9 & 34.5 & 39.7 & 39.0 & 39.4 \\
\hline 140 & 81.6 & 80.0 & 80.8 & 8.87 & 8.52 & 8.70 & 36.0 & 34.7 & 35.3 & 40.0 & 39.3 & 39.6 \\
\hline S.Em \pm & 0.8 & 0.8 & 0.6 & 0.11 & 0.13 & 0.09 & 0.4 & 0.4 & 0.3 & 0.6 & 0.6 & 0.4 \\
\hline $\mathrm{CD}(\mathrm{P}=0.05)$ & 2.4 & 2.2 & 1.6 & 0.31 & 0.37 & 0.24 & 1.1 & 1.1 & 0.8 & NS & NS & NS \\
\hline
\end{tabular}


Table 3: Effect of tillage, seed rate and nitrogen levels on economics of wheat

\begin{tabular}{|c|c|c|c|c|c|c|}
\hline \multirow{2}{*}{ Treatments } & \multicolumn{3}{|c|}{ Net returns (Rs. ha $\left.{ }^{-1}\right)$} & \multicolumn{3}{|c|}{ B:C ratio } \\
\hline & 2015-16 & 2016-17 & Pooled & 2015-1 & 2016-1 & Pooled \\
\hline \multicolumn{7}{|c|}{ Tillage } \\
\hline ZT & 38817 & 36870 & 37844 & 2.70 & 2.62 & 2.66 \\
\hline MT & 40256 & 38262 & 39259 & 2.64 & 2.56 & 2.60 \\
\hline CT & 41527 & 38708 & 40118 & 2.56 & 2.46 & 2.51 \\
\hline S.Em \pm & 747 & 731 & 522 & 0.03 & 0.03 & 0.02 \\
\hline $\mathrm{CD}(\mathrm{P}=0.05)$ & 2265 & 2217 & 1514 & 0.09 & 0.09 & 0.06 \\
\hline \multicolumn{7}{|c|}{ Seed rate $\left(\mathrm{kg} \mathrm{ha}^{-1}\right)$} \\
\hline 100 & 39460 & 37030 & 38245 & 2.63 & 2.52 & 2.58 \\
\hline 125 & 40940 & 38863 & 39902 & 2.64 & 2.56 & 2.60 \\
\hline S.Em \pm & 610 & 597 & 427 & 0.03 & 0.02 & 0.02 \\
\hline $\mathrm{CD}(\mathrm{P}=0.05)$ & NS & 1810 & 1236 & NS & NS & NS \\
\hline \multicolumn{7}{|c|}{ Nitrogen levels $\left(\mathrm{kg} \mathrm{ha}^{-1}\right)$} \\
\hline 80 & 32915 & 32855 & 32885 & 2.35 & 2.36 & 2.35 \\
\hline 100 & 39687 & 36974 & 38331 & 2.63 & 2.51 & 2.57 \\
\hline 120 & 43289 & 40382 & 41835 & 2.76 & 2.64 & 2.70 \\
\hline 140 & 44910 & 41576 & 43243 & 2.80 & 2.67 & 2.73 \\
\hline S.Em \pm & 988 & 743 & 618 & 0.04 & 0.03 & 0.03 \\
\hline $\mathrm{CD}(\mathrm{P}=0.05)$ & 2809 & 2112 & 1735 & 0.11 & 0.09 & 0.07 \\
\hline
\end{tabular}

\section{Conclusion}

The planting of wheat with conventional tillage and $125 \mathrm{~kg}$ seed rate in conjunction with $120 \mathrm{~kg} \mathrm{~N} \mathrm{ha}^{-1}$ gave significantly higher grain, straw and biological yields. The conventional tillage and $125 \mathrm{~kg}$ seed rate in conjunction with $120 \mathrm{~kg} \mathrm{~N} \mathrm{ha}^{-1}$ gave significantly higher net returns and B:C ratio of wheat.

\section{References}

1. Anonymous. Vital Agriculture Statistics. Directorate of Agriculture, Jaipur, Rajasthan, 2015b.

2. Chhokar RS, Sharma RK, Jat GR, Pundir AK, Gathala MK. Effect of tillage and herbicides on weeds and productivity of wheat under rice-wheat growing system. Crop Prot. 2007; 26:1689-1696.

3. Idnani LK, Kumar A. Relative efficiency of different irrigation schedules for conventional, ridge \& raised bed seeding of wheat (Triticum aestivum). Indian Journal of Agronomy. 2012; 57(2):148-151.

4. Iqbal N, Akbar N, Ali M, Sattar M, Ali L. Effect of seed rate and row spacing on yield and yield components of wheat (Triticum aestivum L.). Journal of Agricultural Research. 2010; 48(2):151-156.

5. Kumar R, Yadav DS. Effect of zero and minimum tillage in conjunction with nitrogen management in wheat (Triticum aestivum) after rice (Oryza sativa). Indian Journal of Agronomy. 2005; 50(1):54-57.

6. Ladha JK, Kumar V, Alam MM, Sharma S, Gathala M, Chandna $\mathrm{P}$ et al. Integrating crop and resource management technologies for enhanced productivity, profitability, and sustainability of the rice-wheat system in South Asia. In: Ladha, J.K et al. (Eds.), Integrated crop and resource management in the rice-wheat system of South Asia. International Rice Research Institute, Los Banos, Philippines, 2009, 69-108.

7. Laghari GM, Oad FC, Tunio S, Chachar Q, Gandahi AW, Siddiqui MH et al. Growth and yield attributes of wheat at different seed rates. Sarhad Journal of Agriculture. 2011; 27(2):177-183.

8. Mahboob A, Arian AM, Khanzada S, Mazher H, Naqive M Umer, Nisar AN. Yield and quality parameters of wheat genotypes as affected by sowing dates and high temperature stress. Pak. J Bot. 2005; 37(3):575-584.
9. Mitra B, Mookherjee S, Das S. Performances of wheat (Triticum aestivum) under various tillage and nitrogen management in sub-Himalayan plains of West Bengal. Journal of Wheat Research. 2014; 6(2):150-153.

10. Panse VG, Sukhatme PV. Statistical methods for agricultural workers. Indian Council of Agricultural Research, New Delhi, 1985

11. Saharawat YS, Singh B, Malik RK, Ladha JK, Gathala M, Jat ML et al. Evaluation of alternative tillage and crop establishment methods in a rice-wheat rotation in North Western IGP. Field Crops Res. 2010; 116:260-267.

12. Sandhu RS, Gill BS, Chahal PS. Competitive ability of wheat (Triticum aestivum L.) against wild oats (Avena ludoviciana Dur.) as influenced by date of sowing, seed rate and spacing. Indian Journal of Ecology. 2010; 37(1):97-100.

13. Sharma SN, Singh RK. Seed rate and weed management on yield and nutrient uptake of wheat (Triticum aestivum). Indian Journal of Agricultural Sciences. 2011; 81(12):1174-1179.

14. Tigabu R, Asfaw F. Effects of seed rate and row spacing on yield and yield components of bread wheat (Triticum aestivum L.) in Dalbo Awtaru Woreda, Wolaita Zone, Southern Ethiopia. Journal of Biology, Agriculture and Healthcare, 2016; 6(7):58-67.

15. Watson DJ, Thorne GN, French SAW. Analysis of growth and yield of winter and spring wheat. Ann. Bot. 1963; 27:1-22. 